\title{
In silico, in vitro and in vivo Tests of Ficus deltoidea Jack Leaves Extract as Inhibitor for $\beta$-Catenin Expression in Colon Carcinogenesis Model
}

\author{
Kusmardi Kusmardi ${ }^{1}$, Tedjo Aryo ${ }^{2}$, Wuyung Puspita Eka' ${ }^{1}$, Fadilah Fadilah², Priosoeryanto Bambang Pontjo ${ }^{3}$, \\ Fachri Wilzar ${ }^{*}$
}

\section{Kusmardi Kusmardi ${ }^{1}$, Tedjo Aryo ${ }^{2}$, Wuyung Puspita Eka ${ }^{1}$, Fadilah ${ }^{2}$, Priosoeryanto Bambang Pontjo $^{3}$, Fachri Wilzar ${ }^{*}$}

\section{'Department of Anatomic Pathology, Faculty of Medicine, Universitas Indonesia, Jakarta, INDONESIA. 2Deparment of Chemisty, Faculty of Medicine Universitas Indonesia, Jakarta, INDONESIA. \\ ${ }^{3}$ Laboratory of Pathology, Faculty of Veterinary, Institut Pertanian Bogor, Bogor, INDONESIA. \\ ${ }^{4}$ Drug Development Research Center, Indonesian Medical Education and Research Institute, Faculty of Medicine Universitas Indonesia, INDONESIA. \\ Correspondence \\ Wilzar Fachri}

Salemba Raya Street, $6^{\text {th }}$, IMERI Building Medical Faculty $11^{\text {th }}$ Floor, Universitas Indonesia, INDONESIA.

Phone no: +62 2131930302

E-mail:wilzar.fachri01@webmail.ui.ac.id

History

- Submission Date: 05-12-2017;

- Review completed: 27-02-2018.

- Accepted Date: 05-03-2018

DOI : 10.5530/pj.2018.4.137

Article Available online

http://www.phcogj.com/v10/i4

Copyright

(c) 2018 Phcog.Net. This is an openaccess article distributed under the terms of the Creative Commons Attribution 4.0 International license.

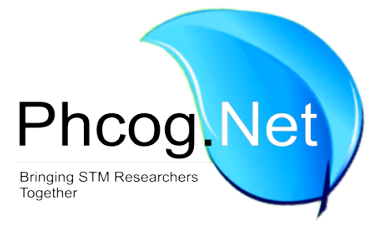

\begin{abstract}
Context: Ficus deltoidea Jack leaves extract as anticolorectal cancer. Aims: This study aims to analyze the potential of FD extract to be an anti-colon cancer by investigating the extract capability in reducing $\beta$-catenin expression and inhibiting colon cancer cells growth. Settings land Design: The research was conducted in Medical Faculty Universitas Indonesia with experimental design. Methods and Material: FD ethanol extracts was tested in vitro, in silico and in vivo. In vitro test was conducted to human colon cell lines. In vivo test was conducted to Balb/c mice induced with $10 \mathrm{mg} / \mathrm{kg}$ azoxymethane (AOM) and dextran sodium sulfate $1 \%$ (DSS). The colonic tissue collected was the distal portion. $\beta$-catenin expressions in the cytoplasm and nuclei of the epithelial cells of the colon crypt were semi quantitatively assessed using the immunohistochemistry staining on ten visual fields with 400x magnification. Statistical analysis used: SPSS. Results: FD ethanol extracts inhibit the expression of $\beta$-catenin in the crypt ephitelial cells of mice colon induced with AOM/DSS. The extracts also inhibit the growth of human colon cancer (HCT 116) with $I_{50}$ value of $5.41 \mathrm{mg} / \mathrm{mL}$. Phytochemical screening to the extracts gave three groups of compounds: alkaloid, flavonoid, and tannin. Water fraction is the best fraction. Based on in the results of in silico analysis with molecular docking, FD extract is believed to influence the expression of $\beta$-catenin, in which vitexin and isovitexin are the main candidate compounds to influence the expression of the protein. Conclusion: FD ethanol extract is potential to be an anti-colon cancer proven by the extract capability to reduce $\beta$-catenin expression.

Key words: Azoxymethane, $\beta$-catenin, Ficus deltoidea, Colon carcinogenesis, in silico.

Key Message: These article give the new explanation of the effect from Ficus deltoidea extract as anticolorectal agents with in vitro, in silico and in vivo model.
\end{abstract}

\section{INTRODUCTION}

Ficus deltoidea Jack (FD) belongs to the Moraceae family and widely grown in the islands of Java, Sumatra, Kalimantan and Maluku. FD is also found in Malaysia and Thailand, and grow in a small extent in China. ${ }^{1}$ In Indonesia, FD is known as Tabat Barito for many are found grown well along the Barito river in the South of Kalimantan. In its natural habitat, FD is an Epiphytic grows on another plants or stick to either larger plants or on the rocks upon which it depends for mechanical support but not for nutrients. ${ }^{2,3}$ In Indonesia, the juice of the leaves is commonly used as a hair tonic, herbal remedy for women after delivery, and herbal medicine for diseases associated with postpartum conditions. ${ }^{4,5}$

Many researches have been done to this plant related to its anti-inflammatory, anti-diabetic, anti-melanogenic, and anticancer properties. ${ }^{6,7}$ An anticancer research that was conducted to ovarian cancer cell lines, in vitro showed $\mathrm{IC}_{50}$ values of $224.39 \pm 6.24 \mathrm{pg} / \mathrm{mL}$ for FD aqueous extract and $143.03 \pm 20.21 \mathrm{pg} / \mathrm{mL}$ forFD ethanolic extract. ${ }^{2,8}$

A more extensive study on FD anticancer potential with other types of cancer, both in vitro and in vivo, needs to be performed. In Indonesia, colon cancer is the third most common cancer diagnosed after cervical and breast cancer. As the etiology of colon cancer is associated with inflammation ${ }^{9}$ and the sufferer today shifts to younger age, exploration to Indonesian native herbals for the treatment of this cancer is getting more and more attention. ${ }^{10,11}$

FD contains flavonoid as one of the active compounds. ${ }^{12}$ Flavonoids are associated with antioxidant properties. $^{2}$ while antioxidants are associated with barrier to genome damage. ${ }^{13,14}$ One of the genome belongs to tumor suppressor genes is $\beta$-catenin, which is an important marker in colon carcinogenesis. ${ }^{15,16}$ Based on the above, this study was conducted to examine the potential of FD extract on the expression of $\beta$-catenin, in silico in vivo and in vitro. In vivo 
test was conducted to mice, in which the carcinogenesisis induced with azoxymethane and dextran sodium sulfate. In vitro test was conducted to human colon cell lines.

\section{MATERIALS AND METHODS}

\section{Ficus deltoidea Jack (FD)}

Fresh FD plants were obtained from their natural habitat in Tabat Barito Conservation Areas, Mandalawangi Resort, Gunung Gede Pangrango National Park, Bogor. FD grows well in the temperature range of $18.3^{\circ} \mathrm{C}-23.1^{\circ} \mathrm{C}$, relative humidity of $80-84 \%$, and in the range ofland slope of $4-24 \%$ with various slope directions. ${ }^{17}$ The plants were identified at the Herbarium Bogoriense, Bogor, Indonesia.

\section{FD Extract Preparation}

Ficus deltoidea fresh leaves $( \pm 1.5 \mathrm{~kg})$ was washed and dried under the sunlight. After the leaves completely dried and free of water, the leaves was grounded to powder using a blender. The powder was then sieved with a 40 -mesh sieve and weighed $(500 \mathrm{~g})$ and kept in a clean and tightly sealed container.

The leaves powder of Ficus deltoidea was put into an erlenmeyer flask, solvent was then added and extraction was performed by sonication for $15 \mathrm{~min}$. The material to solvent ratio was 1:10. To the resulting residue it was added the same solvent and extraction was performed with the same procedure. The macerates were then pooled and dried with a rotary evaporator. The resulting extract was weighed and the yield was determined. ${ }^{18}$

\section{Flavonoid Content Measurement}

Flavonoid content was measured using the method of Dzolin, et al. (2015)..$^{12}$ Catechin was used as a standard in varying concentrations of $20,40,60,80$ and $100 \mathrm{mg} / \mathrm{mL}$. One $\mathrm{mL}$ aliquot of the extract and catechin standard solution were each diluted in $4 \mathrm{~mL}$ distilled water. To the solutions, it was added with $0.3 \mathrm{~mL}$ of $5 \% \mathrm{NaNO}_{2}$ and after $5 \mathrm{~min}$, $0.3 \mathrm{~mL} 10 \% \mathrm{AlCl}_{3}$ was added. To this mixture, it was added $2 \mathrm{~mL} \mathrm{NaOH}$ $1 \mathrm{M}$ and $2.4 \mathrm{~mL}$ distilled water, and mixed thoroughly. The pink color appeared in the solution was measured using UV spectrophotometer at a wavelength of $519 \mathrm{~nm}$. Total flavonoid was calculated based on $\mathrm{mg}$ catechin equivalents (mg EqCatechin) per g extract. The measurement was conducted in triplet and the average value was determined. ${ }^{12}$

\section{Animals}

Experimental animals used were male Balb/c mice, aged 2-3 months, weighing 20-25 g. Mice were bred and reared in the Laboratory of Experimental Pathology, Department of Anatomic Pathology, Faculty of Medicine, Universitas Indonesia. Mice were kept in a room with temperature of $22 \pm 2^{\circ} \mathrm{C}$ in $12 \mathrm{~h}$ light and $12 \mathrm{~h}$ dark cycle. Mice were fed with standard pellet and ad libitum drinking water. Before being used in the experiment, the mice were confirmed free from parasitic diseases. ${ }^{19}$ Animals were reared and treated in accordance with the Guide for the Care and Use of Laboratory Animals of the Animal Care and Use Committee, and had gained approval from the Research Ethics Committee of the Faculty of Medicine, University of Indonesia. Animal rearing and treatment were carried out by Felasa certified researchers.

\section{Induction of Colon Carcinogenesis}

Induction of colon carcinogenesis in mice was performed according to the method developed by Tanaka, et al. (2003) and Suzuki, et al. (2006). Mice were injected intraperitoneally with azoxymethane (AOM/Sigma) dissolved in $0.9 \% \mathrm{NaCl}$ at a dose of $10 \mathrm{mg} / \mathrm{kg}$ of body weight for one administration. Post-AOM induction the mice were given standard feed and mineral water for one week. For the next one week, the water was replaced with aquadest containing $1 \%$ dextran sodium sulfate (DSS/ Sigma). The mice were reared for first, second, third, and forth month until the time of sacrifice to get the colon tissue. The colonic tissue collected is the distal portion..$^{20}$

\section{FD Extract Administration}

FD extract was administered orally to each mouse from the third week or after the completion of DSS administration. Mice were divided into 4 groups, each group consisting of 6 animals. The mice grouping are as follows: the first group or negative control group is the group of mice induced with AOM/DSS and only received distilled water during the treatment. The second group is mice induced with AOM/DSS and received 12.5\% w/v (low dose) of FD ad libitum. Group 3 received 25\% $\mathrm{w} / \mathrm{v}$ (medium dose) of FD, while group 4 received $50 \% \mathrm{w} / \mathrm{v}$ (high dose) of FD. At the end of first, second, third, and forth month after FD administration, the mice were sacrificed.

\section{Immunohistochemistry staining of $\beta$-catenin Staining}

Mice were sacrificed using ketamine-xylazine 16 weeks post-carcinogenesis induction with AOM. Mice colon were removed, cleaned with water, and fixed with $10 \%$ phosphate buffered formalin. Distal colon tissue sections were embedded in paraffin. Tissues were cut to a thickness of $4 \mu \mathrm{m}$ for immunohistochemistry staining. After deparaffinization and rehydration, the slides were immersed into $0.01 \mathrm{M}$ citrate buffer $(\mathrm{pH}$ 6.0) in microwave for $5 \mathrm{~min}$. $3 \% \mathrm{H}_{2} \mathrm{O}_{2}$ were added in drops for $5 \mathrm{~min}$ at room temperature to remove endogenous peroxide. The slides were then incubated with rabbit polyclonal $\beta$-catenin antibody (dilution 1:250; Abcam, Inc., Cambridge, MA) in PBS for $2 \mathrm{~h}$ at room temperature in humidity chamber, followed by incubation overnight at $4^{\circ} \mathrm{C}$. N-Universal (Dako) was used as negative control. The slides were then incubated with an appropriate secondary antibody for $1 \mathrm{~h}$ at room temperature followed by incubation with HRP-conjugated streptavidin for $30 \mathrm{~min}$. Protein was visualized using $3,3^{\prime}$-diaminobenzidine (DAB) for $10 \mathrm{~min}$ at room temperature. Harris hematoxylin, a counterstain, was then added, dehydrated and mounted.

\section{Immunohistochemistry Staining Interpretation}

$\beta$-catenin expressions in the cytoplasm and nuclei of the epithelial cells of the colon crypt were semi quantitatively assessed using the criteria of Walker on ten visual fields with 400x magnification. Expressions were reported according to the following score: $0=$ negative, $1=<10 \%$ of cells stained, $2=10-50 \%$ of cells stained, $3=50-80 \%$ of cells stained, $4=80-100 \%$ of cells stained. The resulting scores were summed up and the average value was determined (Walker, 2006). Human colonic adenocarcinoma tissue was used as positive control for $\beta$-catenin staining and the tissue samples that were not treated with the primary antibody were used as negative control.

\section{In vitro experiments}

In this study, in vitro experiment used human colon cancer cell line HCT 116 obtained from the Research Institute for Fisheries and Maritime Affairs, Republic of Indonesia. Cells were maintained in $\mathrm{CO}_{2}$ incubator with $5 \% \mathrm{CO}_{2}$ level, temperature of $37^{\circ} \mathrm{C}$ in RPMI medium, 5\% FCS, $1 \%$ penicillin and streptomycin. Confluent cells were harvested by the addition of $0.5 \%$ trypsin. Only confluent cells used in the toxicity test using MTT method. ${ }^{21}$ This method checks for mitochondrial dehydrogenase enzyme in living cells. The enzyme will reduce the yellow MTT reactant to blue formazan. First, the extract samples were diluted and added to the wells of a 96-well plate. The extract samples were diluted to concentrations of $6.25 \mu \mathrm{g} / \mathrm{ml}, 12.5 \mu \mathrm{g} / \mathrm{ml}, 25 \mu \mathrm{g} / \mathrm{ml}$, $50 \mu \mathrm{g} / \mathrm{ml}, 100 \mu \mathrm{g} / \mathrm{ml}, 200 \mu \mathrm{g} / \mathrm{ml}, 400 \mu \mathrm{g} / \mathrm{ml}$ and $800 \mu \mathrm{g} / \mathrm{ml}$, and each 
was made in triplet. After $48 \mathrm{~h}$, the supernatant was removed and the precipitate was washed using PBS (phosphate buffered saline) and then incubated with $10 \mu \mathrm{lMTT}$ reactant $(5 \mathrm{mg} / \mathrm{mL})$ in RPMI 1640 medium for $4 \mathrm{~h}$ at $37^{\circ} \mathrm{C}$. The reaction was then centrifuged at $500 \mathrm{rpm} / \mathrm{min}$ for $5 \mathrm{~min}$. The supernatant was removed again and $100 \mu \mathrm{l}$ ethanol was added to dissolve formazan crystals. Afterwards, the absorbance (OD) was read at $595 \mathrm{~nm}$ and the absorbance of the cells in the control group was considered as $100 \%$. OD values are directly proportional to the number of cells, which means the smaller the OD value, the smaller the number of the living cells.

The resulting OD values showed the number of the living cells. Percent inhibition of each concentration of the treatment is calculated by using the following formula:

$$
\% \text { inhibition }=\frac{\text { OD control }- \text { OD treatment }}{\text { OD control }} \times 100
$$

Percent inhibition is calculated for each well, and the mean value for every triplet is determined. $\mathrm{IC}_{50}$ is obtained from the linear equation of the \%inhibition against concentration graph. The intercept and the capability to inhibit $50 \%$ cell growth were observed as a measure for cytotoxicity. $^{22}$

\section{RESULTS}

\section{In silico Test}

Two-dimensional modelling of compounds in FD leaves extracts was conducted by using the database in www.chempider.org. The search for compounds in the PubMed database resulting in, among others, vitexin, isovitexin, epi (catechin), and epi (afzelechin). The results for molecular fixation of protein ligands/targets (the compounds contained inthe FD extract) can be seen in Table 1 .

\section{Phytochemical Test}

Phytochemical screening to the ethanol extract of FD was conducted by using three fractions: hexane, ethyl acetate, and water. Water fraction resulting in three groups of compounds: alkaloids, flavonoids, and tannins. Water fraction is the best of the three (Table 2).Total flavonoid content is reported in $\mathrm{mg}$ equivalent of cathecin (mg Eq Cathecin) per $\mathrm{g}$ of extract and the results from three measurements are278, 302and $314 \mathrm{mg}$ Eq Cathecin/gram with an average of $298 \mathrm{mg}$ Eq Cathecin/gram.

\section{In vitro Test}

Table 3 shows the results of optical density for each group of dose performed in triplet. From the results of optical density, it was then determined the percent inhibition for each group. The group for dose treatment of $6.25 \mu \mathrm{g} / \mathrm{ml}$ had percent inhibition of $82.19 \%, 12.5 \mu \mathrm{g} / \mathrm{ml}$ (93.77\%), $25 \mu \mathrm{g} / \mathrm{ml}$ (94.77\%), $50 \mu \mathrm{g} / \mathrm{ml}$ (94.40\%), $100 \mu \mathrm{g} / \mathrm{ml}(93.77 \%)$, $200 \mu \mathrm{g} / \mathrm{ml}$ (92.53\%), $400 \mu \mathrm{g} / \mathrm{ml}$ (92.90\%), and $800 \mu \mathrm{g} / \mathrm{ml}(90.66 \%)$.

Figure 1 presents microscopic observation under Dino Eye microscope for HCT 116 cells, which weretreated with various concentrations of FD leaves extract.

$\mathrm{IC}_{50}$ is calculated using Microsoft Excel 2013 by connecting the FD extract concentration ( $\mathrm{x}$-axis) and the percent inhibition ( $\mathrm{y}$-axis), from which a linear equation was then created (Figure 2).

Based on the line equation in Figure 2, $\mathrm{IC}_{50}$ can be calculated as follows:

$$
\begin{array}{ll}
50 & =3.2006 \mathrm{x}+32.676 \\
50-32.676 & =3.2006 \mathrm{x} \\
17.324 & =3.2006 \mathrm{x} \\
\mathrm{x} & =\frac{17.324}{3.2006}=5.412735 \sim 5.41 \mu \mathrm{g} / \mathrm{ml}
\end{array}
$$

Thus, it is obtained $\mathrm{IC}_{50}=5.41 \mu \mathrm{g} / \mathrm{ml}$

\section{The Expression of $\beta$-catenin}

Generally, $\beta$-catenin expressions inthe colon tissue of mice after FD extract administration were found in the cytoplasm and the cell membrane (Figure 3). Based on the number of brown-stained crypt epithelial cells of mice colon, the expressions were scored $0-4$. Score $0=$ negative, $1=<10 \%$ cells stained, $2=10-50 \%$ cells stained, $3=50-80 \%$ cells stained, and $4=80-100 \%$ cells stained.

Table 4 shows the average score for $\beta$-catenin expression in the crypt epithelial cells of mice colon after FD extract administration with various doses and in various duration of administration.

\section{DISCUSSION}

\section{Phytochemical Test}

The results for phytochemical screening tests of three FD extract fractions can be seen in Table 2. From the n-hexane fraction, it was only obtained triterpenoid compounds, while ethylacetate fraction only contained

\begin{tabular}{|c|c|c|c|c|c|}
\hline Target & Substances & $\Delta \mathbf{G}(\mathrm{Kcal} / \mathrm{mol})$ & pKi $(\mu \mathrm{M})$ & H donor & H acceptor \\
\hline \multirow[t]{3}{*}{ GSK3 $\beta$} & vitexin & -13.99 & 9,98 & 1 & 4 \\
\hline & isovitexin & -11.47 & 7.71 & 1 & 0 \\
\hline & catechin & -12.29 & 8.61 & 1 & 1 \\
\hline \multirow[t]{3}{*}{ APC } & vitexin & -11.72 & 11.33 & 4 & 4 \\
\hline & catechin & -10.85 & 10.07 & 4 & 3 \\
\hline & afzelechin & -10.31 & 7.92 & 0 & 3 \\
\hline \multirow[t]{2}{*}{ Axin } & vitexin & -14.00 & 9.30 & 3 & 3 \\
\hline & isovitexin & -14.60 & 11.39 & 5 & 3 \\
\hline \multirow[t]{2}{*}{ Wnt } & vitexin & -1.28 & 9.69 & 3 & 2 \\
\hline & isovitexin & -10.97 & 5.70 & 1 & 1 \\
\hline B-catenin & vitexin & -11.14 & 10.58 & 5 & 6 \\
\hline NFkB & afzelechin & -11.48 & 5.46 & 0 & 1 \\
\hline \multirow[t]{2}{*}{ MAPK } & vitexin & -11.24 & 7.70 & 5 & 2 \\
\hline & isovitexin & -9.79 & 4.40 & 1 & 2 \\
\hline PPARa & vitexin & -11.90 & 8.23 & 2 & 4 \\
\hline
\end{tabular}
tannins. However, the water fraction contained alkaloids. Flavonoids and tannins. Several phytochemical studies reported that Ficus deltoidea

Table 1: Stability of Gibbs free energy interaction $(\Delta G)$, inhibition constants (pKi), and the number of $H$-donor and $H$-acceptor between the target protein and a candidate compound of FD extract. 
Table 2: Results of Phytochemical Screening of Ficus deltoidea Fractions.

\begin{tabular}{ccccc}
\hline Substances & $\begin{array}{c}\text { Hexane } \\
\text { Fraction }\end{array}$ & $\begin{array}{c}\text { Ethyl Acetate } \\
\text { Fraction }\end{array}$ & $\begin{array}{c}\text { Water } \\
\text { Fraction }\end{array}$ & Color \\
\hline Alkaloid & - & - & + & Broken white \\
Flavonoid & - & - & + & Reddish-yellow \\
Tanin & - & + & + & Blue-black \\
Triterpenoid & + & - & - & Red or purple \\
Saponin & - & - & - & Foam formed for 10 min \\
\hline
\end{tabular}

Table 3: Percent Inhibition of HCT 116 afterincubation for $24 \mathrm{~h}$.

\begin{tabular}{cccccccc}
\hline FD Extract & OD I & OD II & OD III & Median & Min. & Max. & Inhibition (\%) \\
\hline Control & 0.269 & 0.281 & 0.289 & 0.281 & 0.269 & 0.289 & 0.00 \\
6.25 & 0.033 & 0.057 & 0.053 & 0.053 & 0.033 & 0.057 & 82.19 \\
12.5 & 0.019 & 0.012 & 0.019 & 0.019 & 0.012 & 0.019 & 93.77 \\
25 & 0.014 & 0.015 & 0.013 & 0.014 & 0.013 & 0.015 & 94.77 \\
50 & 0.016 & 0.014 & 0.015 & 0.015 & 0.014 & 0.016 & 94.40 \\
100 & 0.020 & 0.014 & 0.016 & 0.016 & 0.014 & 0.02 & 93.77 \\
200 & 0.021 & 0.019 & 0.02 & 0.02 & 0.019 & 0.021 & 92.53 \\
400 & 0.019 & 0.012 & 0.019 & 0.019 & 0.012 & 0.019 & 92.90 \\
800 & 0.028 & 0.023 & 0.024 & 0.024 & 0.023 & 0.028 & 90.66 \\
\hline
\end{tabular}

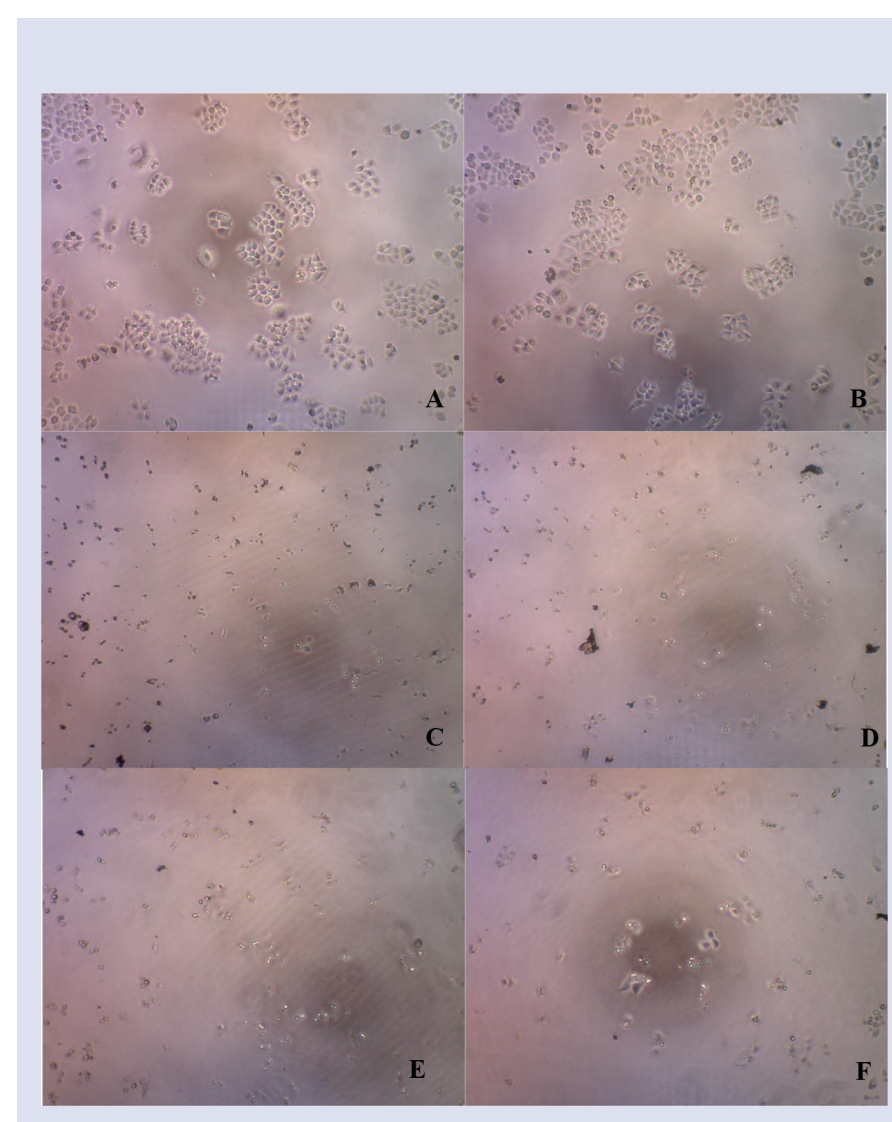

Figure 1: HCT116 cells observation using Dyno Eye microscope. A. Control 1, B. Control 2, C. FD Extract Administration of 50 ppm, D. 25 ppm, E. 12.5 ppm, and F. 6.25 ppm.

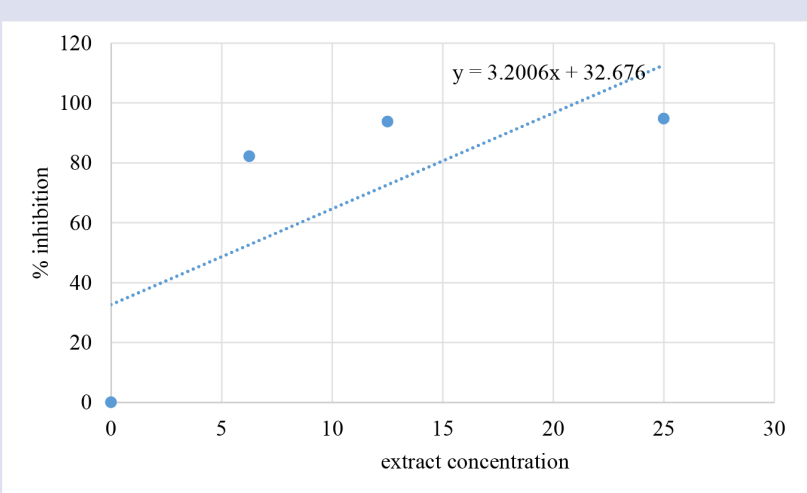

Figure 2: Linear Equation for the determination of $\mathrm{IC}_{50}$ of $\mathrm{FD}$ leaves ethanol extract On HCT 116 Cells.

contains tannins, flavonoids, alkaloids, and carbohydrates. Tannins may be extracted from all parts of the plant, including leaves, branches, stems, roots and fruits. FD is one of the polyphenol-rich plants, which shows in the high content of total phenol and flavonoid.

\section{In silico and in vitro Tests}

Table 1 listedsome most potential candidate-compounds contained in the FD extract that have strong interaction with the target protein involved in $\beta$-catenin pathway in the pathogenesis of colon cancer. The interaction stability can be seen from the Gibbs free energy $(\Delta \mathrm{G}), \mathrm{pKi}$, and the number of $\mathrm{H}$-donors and $\mathrm{H}$-acceptors.Gibbs free energy $(\Delta \mathrm{G})$ represents the strength of the binding affinity of the ligand to the protein. The interaction between ligand and protein can occur if the resulting ligand-protein complex has $\Delta \mathrm{G}$ value lower than zero. The smaller the $\Delta \mathrm{G}$ value, the more stable the complex. Stable interaction between the ligand and the target protein is expected to affect the protein performance that will ultimately produce a pharmacological effect. 
Table 4: Average score for $\beta$-catenin expression after FD extract administration.

\begin{tabular}{|c|c|c|c|c|c|}
\hline \multirow{2}{*}{ Group } & \multicolumn{4}{|c|}{$\begin{array}{l}\text { Duration of Extract Administration } \\
\text { (month) }\end{array}$} & \multirow[t]{2}{*}{$\mathbf{p}$} \\
\hline & 1 & 2 & 3 & 4 & \\
\hline Negative Control & 1.42 & 1.64 & 2.46 & 3.35 & 0.068 \\
\hline Low dose & 1.46 & 1.26 & 1.98 & 2.68 & 0.242 \\
\hline Medium dose & 1.06 & 1.22 & 1.10 & 2.14 & 0.036 \\
\hline High dose & 0.68 & 1.04 & 0.42 & 0.44 & 0.026 \\
\hline Positive Control & 0.98 & 1.24 & 1.26 & 0.22 & 0.019 \\
\hline $\mathrm{P}$ & 0.246 & 0.024 & 0.046 & 0.022 & \\
\hline
\end{tabular}

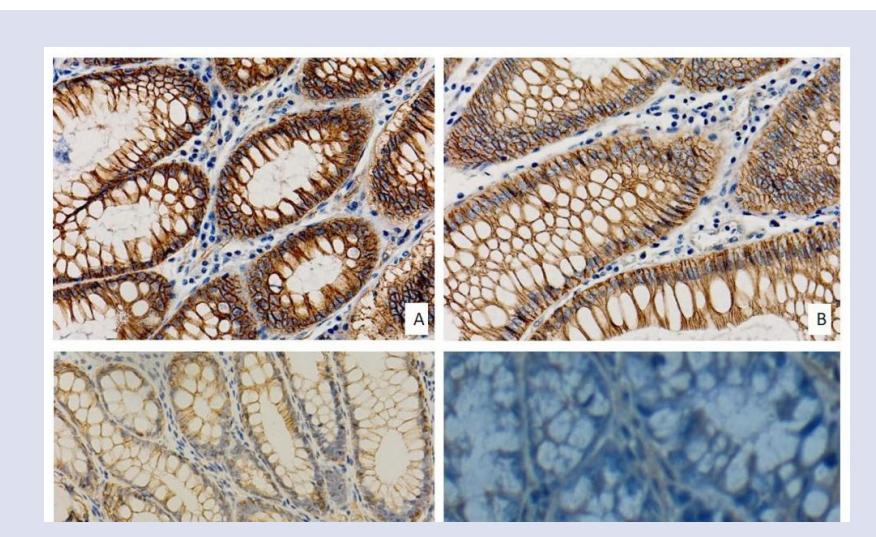

Figure 3: Expression of B-catechin in mice colon tissue.

The other parameter, inhibition constant (pKi), can give an overview on the affinity between the ligand and the target protein. The smaller the Ki value the better the result, which meansthe smaller the Ki value, the equilibrium of the reaction tends to shift toward the complex formation. Binding energy $(\Delta \mathrm{G})$ value and $\mathrm{Ki}$ has a proportional relationship and the value follows the thermodynamic equation below:

$$
\Delta \mathrm{G}=-\mathrm{RT} \ln \mathrm{Ki}
$$

A protein-ligand complex is said to have good binding affinity if the Ki value is in micro molar range. In addition to the value of Gibbs free energy $(\Delta G)$, the interaction stability also influenced by the number of the hydrogenbond formed. Based on the rules of Lipinski, good permeability and absorptivity of a compound will be achieved if the interaction between a compound and a protein receptor is formed by less than 5 (five) $\mathrm{H}$-donor and $\mathrm{H}$-proton.

These hydrogen bonds contribute to the affinity of the ligand to the enzyme/protein due to electrostatic interaction between oxygen or nitrogen atom of the ligand and the hydrogen atom of the amino acid residue of the enzyme/protein or vice versa. The iinteraction between the protein and the ligand in the active site of the protein is also influenced by these electrostatic and steric factors. This interaction will determine the $\Delta \mathrm{G}$ value, so that it is possible to estimate the most stable protein-ligand complex.

From Table 1, based on the results of prediction by molecular docking, the extract of Ficus deltoidea is believed to affect the expression of $\beta$-catenin, in which vitexin and isovitexin are the main candidate compounds influencing theexpression of the protein.

From the in vitro experiment against the human colon cancer cells (HCT 116), it is seen that FD has a relatively high cytotoxic activity. This noticeably high cytotoxicity is associated with phytochemical test results, which showed that FD contains tannins, flavonoids and alkaloids.

\section{$\beta$-catenin expression in in vivo test}

Positive $\beta$-catenin expression is indicated by brown staining of the sample preparation. Scoring to the crypt epithelial cells positive to betacatenin gave an average score value from ten visual fields of 2 (moderate). As shown in Figure 3, the expression occurs in the cytoplasm and the cell membrane. From Table 4, it is shown that colon carcinogenesis occurred in induced mice of the negative control group. In the low-dose group, colon carcinogenesis is not much affected regardless of the duration of FD extract administration. However, in the medium and high dose groups, there is positive progress over time of administration. This is also the case with the positive control group. FD extract administration shows positive progress starting from the second month $(p=0.024)$ continues to the third month $(\mathrm{p}=0.046)$ and the fourth month $(\mathrm{p}=0.022)$.

\section{CONCLUSION}

FD ethanol extracts inhibit the expression of $\beta$-catenin in the crypt ephitelial cells of mice colon induced with AOM/DSS. The extracts also inhibit the growth of human colon cancer (HCT 116) with $\mathrm{IC}_{50}$ value of $5.41 \mathrm{mg} / \mathrm{mL}$. Phytochemical screening to the extracts gave three groups of compound: alkaloid, flavonoid, and tannin. Water fraction is the best fraction. Based on in the results of in silico analysis with molecular docking, FD extract is believed to influence the expression of $\beta$-catenin, in which vitexin and isovitexin are the main candidate compounds to influence the expression of the protein.

\section{CONFLICTING INTEREST}

The authors declare no conflict of interest.

\section{ACKNOWLEDGEMENT}

This research was supported by Directorate General of Higher Education, Ministry of Research, Technology and Higher Education, Republic of Indonesia, under Excellence Higher Education Institution Research Grant 2015-2016. We would also show our gratitude to the Directorate of Research and Community Services, Universitas Indonesia, for facillitating the planning, execution, and periodical monitoring of the research.

\section{ABBREVIATIONS}

FD-Ficus deltoidea ; AOM -Azoxymethane; DSS-Dextran Sodium Sulfate ; MTT3-(4,5-Dimethylthyazol-2-yl)-2,5-Diphenyltetrazolium Bromide ; OD- Optical Density. 


\section{REFERENCES}

1. Abdullah M, et al. Expression of NF-kB and COX2 in colorectal cancer among native Indonesians: the role of inflammation in colorectal carcinogenesis. Acta Med Indones. 2013;45(3):187-92

2. Abdullah $\mathrm{M}$, et al. Molecular profile of colorectal cancer in Indonesia: Is there another pathway? Gastroenterol Hepatol from Bed to Bench. 2012;5(2):71-78.

3. Agustina A. [Conservation Tabat Barito in a National Park Gunung Gede Pangrango: Review of microhabitats characteristics and bioactive leaves]. Thesis. Faculty of Forestry. Bogor Agricultural University.

4. Ministry of Health of the Republic of Indonesia. 2009. [Cancer Registration Agencyof Association of Indonesian Pathologist: Cancer Histopathology Data in Indonesia in 2009]. Jakarta: Yayasan Kanker Indonesia. 2009.

5. Moor $A E$, Anderle $P$, Cantù $C$, Rodriguez $P$, Wiedemann $N$, Baruthio $F$, et al. BCL9 9L- $\beta$-catenin Signaling is Associated With Poor Outcome in Colorectal Cancer.EBioMedicine. 2015;2(12):1932-43.

6. Aristyanti D. [The Effect of Soil Chemistry on the Content Level of Leaf Flavonoid Tabat Barito (Ficus deltoidea Jack.)]. Thesis. Faculty of Forestry. Bogor Agricultural University.

7. Arsianti A, Fadilah, Kusmardi, Tanimoto H, Kakiuchi K. Design, Synthesis, and CytotoxicityEvaluation of Novel Open Chain Analogues of Antimycin A3 as Potential Anti-colorectal Cancer Agents. Asian J Pharmaceutic Clin Res. 2017;13(2):129-36.

8. Bunawan H, Amin NM, Bunawan SN, Baharun SN, Noor NM. Ficus deltoidea Jack: A review on its phytochemical and pharmacological importance. Evidencebased Complement Alt Med. 2014;1-8.

9. Darusman LK. [Extract of Tabat Barito as Anti-Tumor: Usefulness as Jamu, Standardized extracts and Phytopharmaca]. Research Report. Bogor Agricultural University. 2003

10. Dzolin S, Ahmad R, Zain MM, Ismail MI. Flavonoid distribution in four varieties of Ficus deltoidea ( Jack ). J Med Plant Herbal Ther Res. 2015;3:1-9.

11. Fadilah F, Arsianti A, Kusmardi, Tedjo A. Molecular Docking Studies of Opened-
Chain Analoques ofantimycin A 3 as caspases inhibitors of apoptosis in colorectal cancer. Asian J Pharmaceutic Clin Res. 2015;9(3):8-10.

12. Farsi E, Shafaei A, Hor SY, Ahamed MBK, Yam MF, Asmawi MZ, et al. Genotoxicity and acute and subchronic toxicity studies of a standardized methanolic extract of Ficus deltoidea leaves. Clinic. 2013;68(6):865-75.

13. Mähler M, Berard M, Feinstein R, Gallagehr A, Illgen-Wilcke B, Pritchett-Corning K, et al. FELASA recommendations for the health monitoring of mouse, rat, hamster, guinea pig and rabbit colonies in breeding and experimental units. Lab animals. 2014;48(3):178-92.

14. Nohmi T, Tsuzuki T. Possible Mechanisms Underlying Genotoxic Thresholds: DNA Repair and Translesion DNA Synthesis.pp. 2016;49-66. Available at: http:// linkinghub.elsevier.com/retrieve/pii/B9780128016633000042.

15. Shafaei A, et al. Antiangiogenic effect of Ficus deltoidea jack standardised leaf extracts. Trop J Pharm Res. 2014;13(5):761-8.

16. Sulaiman MR, et al. Evaluation of the antinociceptive activity of Ficus deltoidea aqueous extract. Fitoterapia. 2008;79(7-8):557-61.

17. Tanaka T. Development of an inflammation-associated colorectal cancer model and its application for research on carcinogenesis and chemoprevention. Int J Inflam. 2012.

18. Tnah LH, et al. Intraspecific classification of Ficus deltoidea Jack subsp. deltoidea (Moraceae) in Peninsular Malaysia based on morphological and molecular variations. Biochem Syst Ecol. 2016;67:119-28.

19. Wan-Ibrahim WI, Sidik K, Kuppusamy UR. A high antioxidant level in edible plants is associated with genotoxic properties. Food Chem. 2010;122(4):1139-44

20. Yang $Y$. New perspectives on $\beta$-catenin control of cell fate and proliferation in colon cancer. Food Chem Toxicol. 2014;74:14-19

21. Zakaria $Z$, et al. Anti-Inflammatory Activity of the Aqueous Extract of Ficus deltoidea. Biol Res Nurs. 2012;14(1):90-7.

22. Zimisuhara B, et al. Structure and principal components analyses reveal an intervarietal fusion in Malaysian mistletoe Figure (Ficus deltoidea Jack) populations. Int J Mol Sci. 2015;16(7):14369-94.

\section{ABOUT AUTHORS}

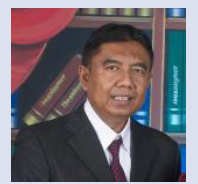

Kusmardi (M.Sc. PhD): Lecturer and Researcher at Pathological Anatomy and Drug Development Research Center Indonesian Medical Education and Research Institute, Faculty of Medicine, Universitas Indonesia. Research interest in Immunology, Pathology, Cancer Biology, Herbal Medicine, Biomedical Sciences, Oncology, Animal Model for Cancer Research, Biostatistic, and Research Methodology.

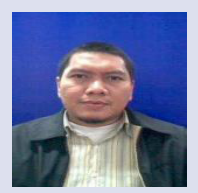

Aryo Tedjo (S.Sc., M.Sc.) :Lecturer and Researcher at Medical Chemistry and Drug Development Research Center Indonesian Medical Education and Research Institute, Faculty of Medicine, Universitas Indonesia. Research interest in Analytical Chemistry and Herbal Medicine.

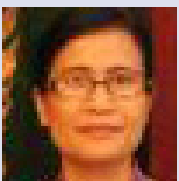

Puspita Eka Wuyung (M.Sc., PhD) Lecturer and Researcher at Pathological Anatomy, Faculty of Medicine, Universitas Indonesia. Research interest in Cancer Biology, Herbal Medicine, Biomedical Sciences, Oncology and Animal Model for Cancer Research.

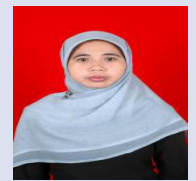

Fadilah (M.Sc., PhD) :Lecturer and Researcher at Medical Chemistry and Drug Development Research Center Indonesian Medical Education and Research Institute, Faculty of Medicine, Universitas Indonesia. Research interest in Bioinformatics, Analytical Chemistry and Herbal Medicine.

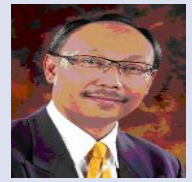

Prof. dr. Bambang Pontjo Priosoeryanto (MS., PhD., AP.Vet): Lecturer and Researcher at Animal Health and Veterinary Education Policy, Faculty of Veterinary Medicine, Bogor Agricultural University. Research interest Veterinary Pathology with specialization of Tumor Pathology, Tissue Culture, Diagnostic Pathology.

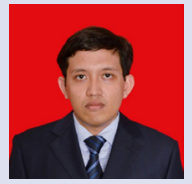

Wilzar Fachri, (M.Sc.) Researcher at Drug Development Research Center Cluster, Indonesian Medical Education and Research Institute, Faculty of Medicine, Universitas Indonesia. Research interest in tissue culture and animal models in drug development.

Cite this article: Kusmardi K, Aryo T, Puspita EW, Fadilah F, Bambang PP, Wilzar F. In silico, in vitro and in vivoTests of Ficus deltoidea Jack Leaves Extract as Inhibitor for $\beta$-Catenin Expression in Colon Carcinogenesis Model. Pharmacog J. 2018;10(4):808-13. 